\title{
DENTAL CARIES EXPERIENCE IN INDIANS OF THE UPPER XINGU, BRAZIL.
}

\author{
Deborah Denise Leal RIGONATTO(1), José Leopoldo Ferreira ANTUNES(2) \& Paulo FRAZÃO(3)
}

\begin{abstract}
SUMMARY
The present study describes the experience of dental caries in Indians communities of the Xingu, in order to supply parameters for further analysis of trends of the disease in Indians. We performed oral health examination in 288 Indians from four communities (Yawalapiti, Aweti, Mehinaku and Kamaiura) living in the southern part of the Xingu National Park, using international criteria defined by the World Health Organization. The outcome measures were the DMFT and dmft scores, and the care index. Indians of the Upper Xingu presented high levels of caries, in all age groups. The average DMFT for 11 to 13-year-old children - 5.93 - was lower than the index measured in 1993 for 12-year-old schoolchildren in nearby cities - 8.23 -, whose United Nations' human development index ranked medium. However, Indians presented a much lower care index, per age group, than these cities, and a high ratio of missing teeth for persons above 20 years old. These observations indicate low incorporation of dental care services. The irregularity of the services programmed for these communities, and the changing dietary and cultural patterns, mainly derived from their contact with the non-indigenous population of Brazil, reinforce the pressing need for health promotion initiatives aimed at these groups.
\end{abstract}

KEYWORDS: Indians of the Xingu; Dental caries; Care index; Community dental health.

\section{INTRODUCTION}

The Xingu River is an affluent of the Amazon River, which crosses the North and Center West regions of Brazil. For centuries, several indigenous communities dwelled in its neighborhoods. In 1961, the Brazilian government has created the Xingu National Park, to protect Indian communities, by demarcating an area at the North of the State of Mato Grosso, bordering the Southern portion of the State of Pará. In 1991 , the population of the whole Park was estimated on 3,500 inhabitants, distributed in 15 Indian groups, spread in three regions, the Upper, the Mid- and the Lower Xingu, which now sum 27,000 km².

In the 1960s, studies conducted within Indian communities in Brazil reported reduced prevalence of dental caries, showing lower indexes than measured to the urban population. NEEL et al. ${ }^{10}$ noted almost complete absence of dental caries in one Xavante village, near the Park. NISWANDER ${ }^{11}$ assessed the oral health of 166 Xavante adults, from 18 to 56 years old, living in another village, which was also located near the Park, and pointed out that the DMFT indexes were relatively low: 1.6 to males and 3.2 to females, being $33 \%$ of them caries free. The author explained the observation of higher indexes of caries to this group as a consequence of six years of permanent contact with a Post of the Indian Protective Service (Serviço de Proteção ao Índio - SPI), which permitted them the access to sugar. The same study also assessed dental caries in 42 Bakairi Indians, a group closely related to other tribes of the
Upper Xingu. Their average DMFT scores ranked very high: 15.2 to adult males and 19.5 to females. The author attributed this observation to a considerable acculturation of this group, consequently to permanent contact with neo-Brazilians, since 1900.

Until the 1970s, the observation of other communities corroborated the register of low experience of dental caries to Indians in Brazil. DONNELLY et $a .^{3}$ stated that tooth decay, to the Yanomami Indians, was directly related to the contact with western culture, as may be induced from the low DMFT indexes (12 to 19 years old) measured to 220 Indians of three groups, dwelling at farther regions of the hinterland, at the border of Brazil and Venezuela: 2.4 in Ocamo; 0.4 in Wabutawatedi; 0.3 in Arata Falls.

TUMANG \& PIEDADE ${ }^{15}$ examined 123 Indians from the Upper Xingu, and evaluated that their DMFS mean score was almost 50\% smaller than the pattern to Brazilian national population. Some years later, HIRATA et al. ${ }^{6}$ examined 210 children of the Upper Xingu, with ages ranging from 3 to 14 years old. They also registered relatively reduced DMFS scores, lower than indicators measured to Brazilian cities without fluoridated water supplies, though higher than the scores observed by TUMANG \& PIEDADE ${ }^{15}$ some years before. Both studies reported that indigenous alimentary habits were still preserved, and that the consuming of white sugar was almost non-existent. These studies were the only surveys assessing caries experience of Upper Xingu Indians.

(1) Rua Ferreira de Araújo, 440, 05428-001 São Paulo, SP, Brasil. Tel. (55 11) 38158738

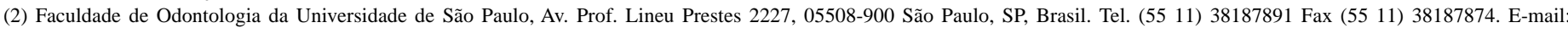
<leopoldo@fo.usp.br>

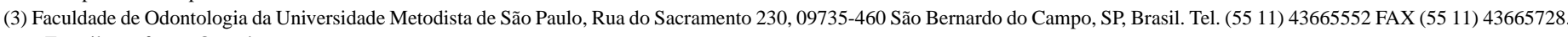
E-mail: <pafrazao@usp.br>

Correspondence to: Deborah D. L. Rigonatto, Rua Ferreira de Araújo 440, 05428-001 São Paulo, SP, Brasil. Tel. (55 11) 38158738 
In spite of former registers of low indexes of caries, during the $1960 \mathrm{~s}$ and 1970 s, there are reasons to suspect that, recently, this situation may have changed. Industrialized foodstuffs have been progressively incorporated into their diet, in a slow and sporadic way. Rice, beans, paste, coffee, cookies, white sugar, candies and soft drinks have been the most consumed items. For several years, the National Foundation for Indians (Fundação Nacional do Índio - FUNAI) provided these products to the Indians. Furthermore, ethnographic descriptions ${ }^{4,7,16}$ registered the sporadic, though highly appreciated, consumption of sweets and sugar derivatives, as lumps of raw hard brown sugar, which the FUNAI used to distribute as gifts to attract the Indians' sympathy. More recently, some individual or collective initiatives - as selling craftsmanship, the ecologic tourism, the production of honey and dried banana - allowed then to acquire merchandises at the nearby cities. In spite of this observation, the relative isolation of the Park and the scarcity of currency have been important factors in establishing Indians' dietary habits, reducing dental risks related to the consumption of industrialized foodstuffs. Otherwise, these factors have also entailed restrictions in the acquisition of products to ensure regular dental hygiene.

The survey of the prevalence and severity of oral disorders in Indians are scarce and difficult to perform. Health professionals have to overcome cultural gaps, as well as the geographic distance between the tribes and nearby cities, in order to access these communities. Health programs and initiatives demand firm institutional support, FUNAI authorization, and the commitment or, at least, the acquiescence of Indians. Different languages and linguistic patterns observed among the groups to be studied also constitute relevant difficulty, which demands supplementary efforts to accomplish these surveys.

The present survey was performed in 1991, with sponsorship of the non-governmental organization Medecins du Monde - MDM, in order to instruct a proposal of renewing a program of health attendance to this area, which had began in 1987. This objective was not achieved, and MDM has departed from the region. In spite of the long lag of time, the present study retakes the data collected by that survey, in order to fulfill the absence of more recent information on this matter. The objective of this paper is to report caries experience of the Upper Xingu Indians, with the purpose of supplying parameters for further studies of trends of the disease in Indian communities, as well as comparative analyses between these tribes and other groups, and the National urban population.

\section{MATERIAL AND METHODS}

From 1967 to 1984, the School of Dentistry of the University of São Paulo maintained the first dental program providing attendance to the Indians of the Upper Xingu. This program consisted of two annual sessions, during two weeks, and was mainly directed toward prevention (Fluor gel application and tooth brushing) and some attendance services, mainly tooth extraction. From July 1987 to March 1991, MDM promoted a program to the formation of indigenous health agents, in collaboration with the FUNAI, the Oswaldo Cruz Foundation and the Paulista School of Medicine, which also included services of dental attendance and oral health promotion. One physician and one dental surgeon, specialized in Community Dental Health, composed the MDM staff. These programs were the only regular initiatives on oral health promotion aimed at the Upper Xingu communities. After 1991, the Paulista School of Medicine maintained one dentist at the Mid-Xingu, who also attended the Upper
Xingu region, though in an irregular way. FUNAI also supplied sporadic dental attendance to the Upper Xingu, by sending staffs, which stayed for some days in each tribe.

In March 1991, we surveyed four out of the ten Indian communities dwelling at the Upper Xingu. The amplitude of the survey was restricted to the tribes that centered the MDM program. The studied groups Yawalapiti, Aweti, Mehinaku and Kamaiura - summed up 494 inhabitants, corresponding to near $45 \%$ of the population estimated to the whole Upper Xingu region. Though we planned to survey all persons of each tribe, the dentist could examine only 288 (58.3\%) of them; being excluded everyone who, for any reason, could not attend the examination. All Indians were examined in one only day, in each tribe, and the examinations summed up 94 Yawalapiti, 56 Aweti, 75 Mehinaku, and 63 Kamaiura, being 131 males and 157 females.

We could survey only $29 \%$ of over-50-year-old adults and $40 \%$ of under-5-year-old children. Most of elderly people refused to participate, arguing that they wouldn't be beneficed by the examination. As to the youngest children, most mothers have not allowed the examination, arguing that they never had toothache. People from the remaining age groups were included in the survey to a greater extent: $69 \%$. The most frequent reasons to the exclusion of examination were the absence of adults, who went on hunting or fishing expeditions, and the reclusion of youths, a custom of their culture, which involves dietary and social relationship restrictions, and is associated to rites of passage from puberty to adulthood.

The oral health examination was directed to the measurement of dental caries experience, according to international criteria standardized by the World Health Organization ${ }^{19}$. All examinations were performed at natural light, and used chemically sterilized equipment. We specially trained Indian health agents to annotate the indications that allowed the calculations of dmft and DMFT indexes, per person, as well as their single components. These indexes are usual population indicators of dental caries experience, and correspond to the number of decayed, missing and filled teeth, for the primary and permanent dentition, respectively. We also registered the care index, a measure described by $\mathrm{WALSH}^{18}$ to compare patterns of oral health in different countries, which is easily calculated by the ratio of the mean number of filled teeth to the global index, both for the dmft and the DMFT scores.

One only dentist - specially trained by the National School of Public Health, on WHO's basic methods for oral health surveys - undertook all the examinations. We have not assessed measures of intra-examiner agreement, as a consequence of the Indian resistance to the reexamination.

Teeth filled with temporary materials were considered as filled, and not as decayed, because of the scarcity of resources to provide permanent restorative fillings for all dental treatment needs. Moreover, when there wasn't fuel to operate the diesel powered electric generator, which supplied the energy to the dental office, and it was quite common, dental attendance usually suppressed amalgam application, replacing it by IRM (intermediate restorative material). The use of temporary materials to perform permanent fillings characterizes, till nowadays, the dental attendance provided to the Indian communities of the Xingu, and corresponded to $67.0 \%$ of all dental fillings identified in the present survey. 
The presentation of results was stratified by broad and relatively imprecise age ranges, in an attempt to minimize errors of classification, because the exact register of the age is not a pattern of their culture and, therefore, was not valued by them. To perform age estimation and classification according to the age groups, we followed WHO recommendations, evaluating the stage of dental eruption to children, also considering self-reported or parental information, as well as physical characteristics of children, youths and adults.

We also followed WHO recommendations regarding tooth loss due to trauma or periodontal diseases. While we tried to diagnose these conditions for youngsters and young adults, for 30 year and older subjects, we classified as "missing" all teeth coded "4" or " 5 ", i.e. missing due to caries or for any other reason. Although this procedure may overestimate caries indexes for elderly people, we observe that the absence of tooth extraction due to orthodontic or prosthetic reasons among Indians in Brazil contributed for improving the profile of the survey.

To perform the statistical analysis, we used the software Statistical Package for the Social Sciences - SPSS 8.0 1997. We also present tables and graphics summarizing the observations, and refer to other studies on caries experience of other Indian communities, as well as National urban population data on the matter, in order to subsidize comparative analyzes.

\section{RESULTS}

Tables 1 and 2 show the mean and standard deviation of, respectively, dmft and DMFT scores measured to the Indians of the Upper Xingu, according to their age groups, as well as the number of Indians examined. These tables also register low values for the calculated ratio of care index, as related to the primary and permanent dentition. Children younger than 5 years old constitute one of the groups with lowest adherence to the survey. In spite of this fact, we stress the observation of only $21.95 \%$ of them caries free. For the other age groups, only two teenagers were caries free, one 14-16, the other 17-20 years old.

We have not discriminated the surveyed data by gender and by community, as a consequence to the reduced number of subjects in each category, a factor that impaired age stratification. However, we point out that no remarkable differences could be observed to the comparison of caries indexes (dmft, DMFT and the care index) between males and females, and amongst the four groups studied.

Table 1

Mean and standard deviation for the dmft scores and care index, per age groups, Upper Xingu Indians, 1991

\begin{tabular}{ccccc}
\hline Age group & $\begin{array}{c}\text { Number } \\
\text { of examinations }\end{array}$ & $\begin{array}{c}\text { dmft } \\
\text { Mean }\end{array}$ & $\begin{array}{c}\text { Standard } \\
\text { deviation }\end{array}$ & $\begin{array}{c}\text { Care } \\
\text { index }\end{array}$ \\
\hline 0 to 4 & 41 & 5.76 & 4.86 & $0.00 \%$ \\
5 to 7 & 58 & 8.48 & 4.25 & $1.42 \%$ \\
8 to 10 & 44 & 4.23 & 2.99 & $2.60 \%$ \\
11 to 13 & 28 & 1.04 & 1.99 & $6.73 \%$ \\
\hline
\end{tabular}

Figure 1 shows the division of the dmft index, by its components, according to the age groups, and highlights visual perception of the high frequency of decayed deciduous teeth. Figure 2 shows similar disposition to the DMFT index, emphasizing the high prevalence of missing teeth to the age ranges above 20 years old. We could observe only one edentulous adult above 50 years old, the group with minimum adherence to the survey.

\section{DISCUSSION}

DETOGNI $^{2}$ surveyed dental caries in 258 Indians living in MidXingu, in 1992, and observed significantly higher DMFT scores ( $\mathrm{p}<$ 0.05 ) than those measured in the Upper Xingu: 9.57 to 11- to 13-yearold children, 18.42 to adults from 21 to 30 years old, 21.46 to 31 - to 50year-old adults, and 27.87 for the over 50 s. The differential pattern observed in the dental caries experience in Indians of the Upper and Mid-Xingu should be explained by the observation of their specific dietary, hygienic and cultural habits. However, the amplitude of these phenomena, and the multiplicity of groups dwelling in each region make this task difficult.

The comparative analysis between the Mid- and Upper Xingu data also indicates significantly lower incorporation of dental care services in the Mid-Xingu communities, in the period. While missing and filled teeth represented $61.29 \%$ (95\% confidence interval: from 59.58 to $62.98 \%$ ) of the whole Mid-Xingu DMFT, according to different age groups, the same ratio for the Indians dwelling in the Upper Xingu came to $65.84 \%$ (63.73 to $67.90 \%$ ). We also registered significantly higher incorporation of conservative dental treatments in the Upper Xingu: the care index, for all age groups, ranked $17.55 \%$ (15.93 to $19.29 \%$ ), against only $11.63 \%$ (10.56 to $12.81 \%$ ) in data for the Mid-Xingu. Moreover, dental hygienic education activities and Fluor gel application, promoted by the School of Dentistry of the University of São Paulo, from 1977 to 1982, were concentrated in the Upper Xingu ${ }^{1}$, and this region was the center of the MDM program, which maintained one dentist for almost four years, until 1991.

In 1993, the Brazilian Industry Social Service (Serviço Social da Indústria - SESI) performed a nation-wide survey on schoolchildren's

Table 2

Mean and standard deviation for the DMFT scores and care index, per age groups, Upper Xingu Indians, 1991

\begin{tabular}{ccccc}
\hline Age group & $\begin{array}{c}\text { Number } \\
\text { of examinations }\end{array}$ & $\begin{array}{c}\text { DMFT } \\
\text { Mean }\end{array}$ & $\begin{array}{c}\text { Standard } \\
\text { deviation }\end{array}$ & $\begin{array}{c}\text { Care } \\
\text { index }\end{array}$ \\
\hline 5 to 7 & 58 & 0.90 & 1.84 & $5.77 \%$ \\
8 to 10 & 44 & 4.05 & 3.21 & $11.24 \%$ \\
11 to 13 & 28 & 5.93 & 3.90 & $12.65 \%$ \\
14 to 20 & 37 & 9.14 & 9.19 & $40.24 \%$ \\
21 to 30 & 35 & 13.31 & 5.00 & $24.46 \%$ \\
31 to 50 & 30 & 17.93 & 6.87 & $10.04 \%$ \\
More than 50 & 15 & 19.33 & 7.54 & $2.76 \%$ \\
\hline
\end{tabular}




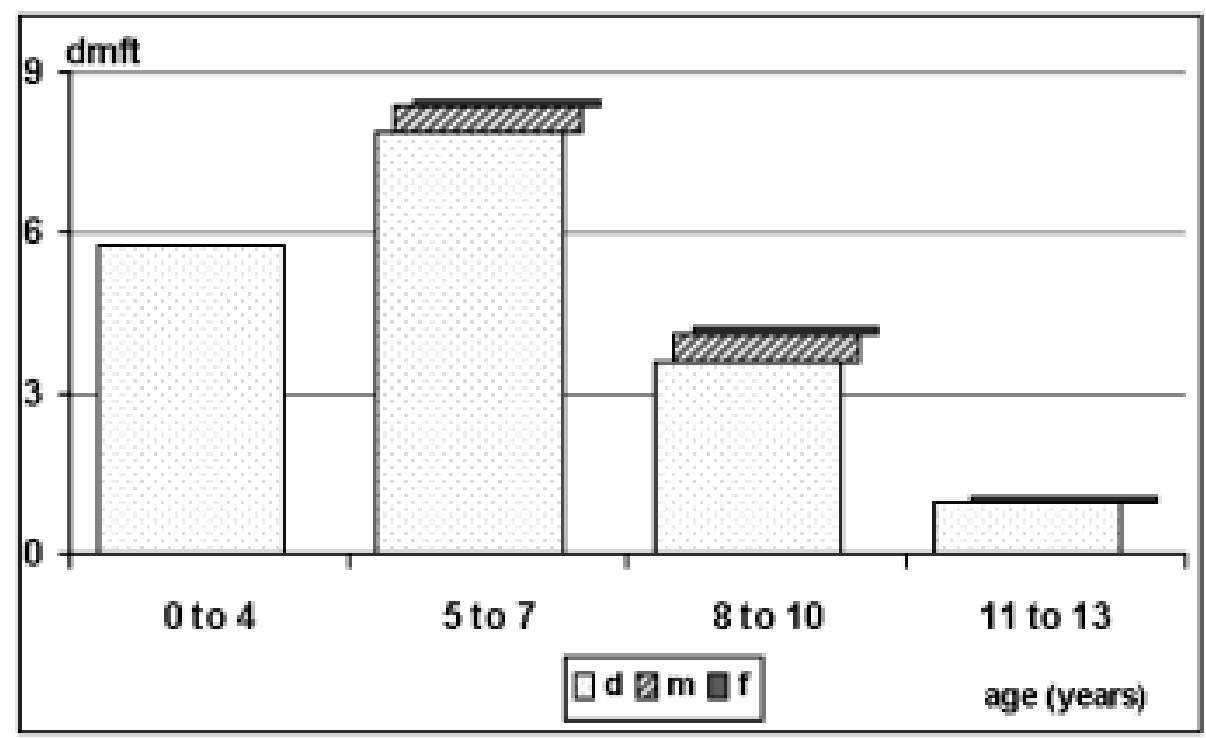

Fig. 1 - dmft scores, per age groups and components, Upper Xingu Indians, 1991.

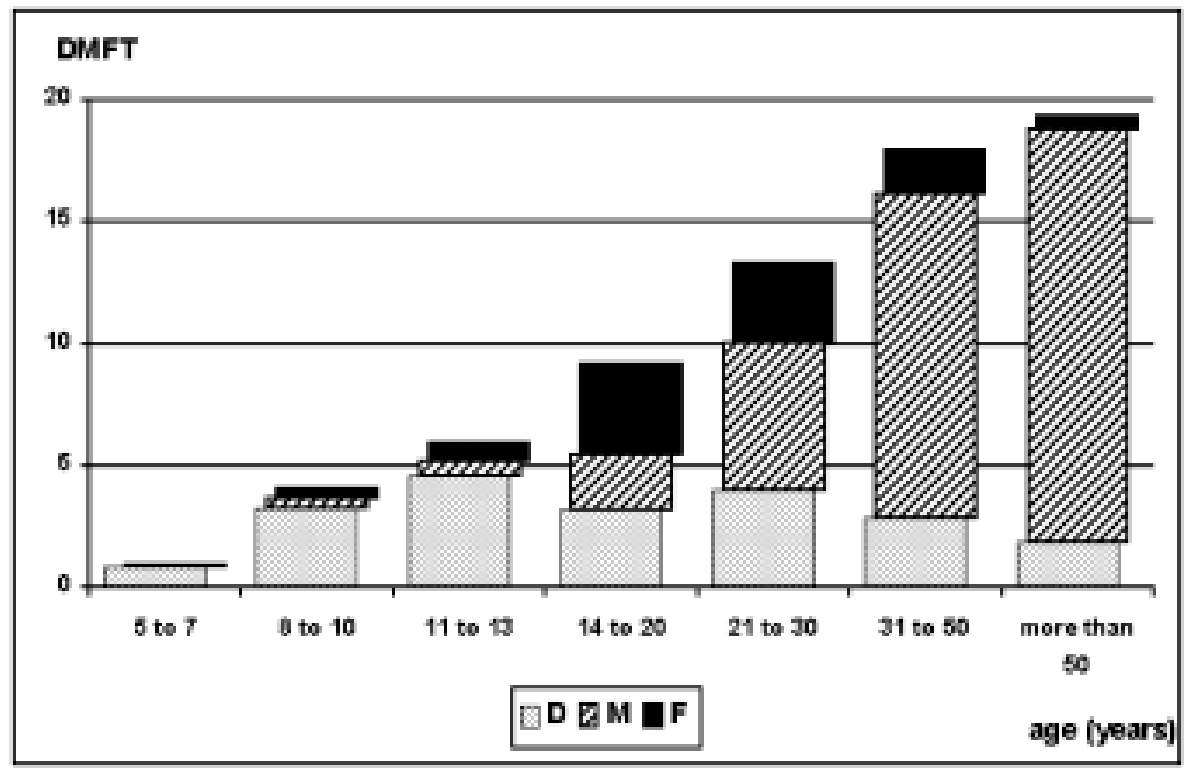

Fig. 2 - DMFT scores, per age groups and components, Upper Xingu Indians, 1991.

oral health indicators ${ }^{13}$. In Brazilian Center West region, the survey included cities whose rank on the Human Development Index, measured in 1991 by the United Nations Development Program - UNDP, indicates a medium profile of socioeconomic conditions, according to the UNDP parameters": Cuiabá (near 400,000 inhabitants), ranked 0.784, Cáceres (near 70,000 inhabitants), ranked 0.580, and Nobres (near 15,000 inhabitants), ranked 0.626. Oral health examination in the sampled subjects of these cities measured 5.74 to the dmft index of 6-year-old children ( $46.70 \%$ care index), while Upper Xingu Indians (5 to 7 years old) measured 8.48 (1.42\% care index). To 12-year-old children, the urban survey measured 8.23 to the DMFT (23.10\% care index), while Upper Xingu Indians (11 to 13 years old) measured 5.93 (12.65\% care index).

WORTHINGTON \& CRAVEN $^{20}$ verified a strong negative relationship between the care index and the dmft and DMFT scores, indicating greater incorporation of conservative dental treatments in groups with reduced disease levels. This statement could be observed in the comparison of indexes related to the primary dentition, with the urban 
population dwelling at the Brazilian Center West region ranking lower dmft and higher care index than the Indians. However, the register of a lower care index in 11- to 13-year-old Indian children, even with concomitant lower DMFT, points to a worse profile of dental attendance of Upper Xingu communities.

It is difficult to perform comparisons between surveys undertaken in different regions, whose criteria may have been different, and whose samples differ in socioeconomic and cultural characteristics. Despite these restrictions, we tried to remark some observations from the international literature, regarding Indian oral health status.

WALDMAN ${ }^{17}$ observed worse indicators of dental caries experience to Indians than to urban population, while comparing the average DMFT measured to all U.S. 5- to 17-year-old subjects, in 1986-1987 (1.97 DMFT, $49.9 \%$ caries free, $83.4 \%$ care index), and American Indian and Alaskan Native 5- to 19-year-old subjects (5.9 DMFT, 19\% caries free, $53 \%$ care index). Although these indexes highlight the impaired oral health status of Native Americans, in relation to American urban population, they also point to the fact that the Indians of the Upper Xingu have still worse indexes of caries.

O'SULLIVAN et al. ${ }^{12}$ examined 2,003 Navajo children aged 3-5 years in the Head Start program, and found the elevated value of 6.62 to the $\mathrm{dmft}$ index. However, they also registered that approximately $70 \%$ of the dmfs in this population comprised treated surfaces. This register strongly contrasts with observations from Table 1, which remarks the reduced value for the care index measured to the primary dentition, in the present sample. MARCUS et al. ${ }^{8}$ studied 35-44 year-old Navajo adults, and also observed a better profile to the caries experience, in relation to the Upper Xingu Indians: from the 13.54 DMFT, 57.39\% corresponded to filled teeth (care index).

HARRISON \& DAVIS ${ }^{5}$ studied dental caries experience of 5- to 15 year-old Native children of British Columbia, Canada, and observed higher indexes than those measured to the urban population of the same age and region. They also observed that the ratio of caries-free Native children increased from $21.3 \%$, in 1980 , to $31.2 \%$ in 1988 , while the average DMFT to 13-year-old children decreased from 9.1 to 6.0, in the same period. These authors attributed the improvement on oral health indicators to the application of preventive actions, as the use of fluoride tablets or rinses, the introduction of fissure sealants, and instructions on oral hygiene. Although we have not surveyed longitudinal data, nor have studied the trends on Indian oral health indicators, we suggest that the increasing contact with the National urban population, and the absence of preventive actions to the Upper Xingu may have contributed to their bad profile of caries indexes.

\section{FINAL COMMENTS}

Darcy RIBEIRO ${ }^{14}$ reported that the Xingu National Park was created with the following objectives: protecting Indian territory against invasions, preventing indigenous populations from the effect of dissociation promoted by interethnic contact, and providing resources of health care to these populations. Indeed, these objectives were in part achieved, and one may state the benefic effects of the Park, by verifying the remarkable increase on Indian population after its creation. Moreover, the delimitation of Indians territory contributed to reduce the predatory exploration of natural resources, and $\mathrm{RIBEIRO}^{14}$ concluded that, in spite of the contact with Brazilian national society, the Park contributed to preserve most of Indian socioeconomic structures and cultural habits.

However, the high dmft and DMFT scores observed to the Indians of the Upper Xingu, in addition to the low ratio of care index, reinforce the concern with the high levels of dental treatment needs in these communities, and the insufficiency of attendance services as already programmed to the region. The changing feature of dietary habits and cultural patterns, mostly derived from the contact between Indians and the national population, reinforces the pressing necessity of politic formulation directed toward oral health promotion and attendance services, which must consider specific characteristics of the studied groups.

\section{RESUMO}

\section{Experiência de cárie dentária em índios do Alto Xingu, Brasil}

O presente estudo descreve a experiência de cárie dentária em índios do Xingu, visando prover parâmetros para a análise de tendências da doença em comunidades indígenas. Foi efetuado exame bucal em 288 índios de quatro comunidades (Yawalapiti, Aweti, Mehinaku e Kamaiura) situadas na porção sul do Parque Nacional do Xingu, segundo critérios internacionais definidos pela Organização Mundial da Saúde. As medidas utilizadas foram o CPO-D, ceo-d, e o índice de cuidado. Os índios do Alto Xingu apresentaram elevados níveis de cáries, em todos os grupos etários. O CPO-D médio para crianças de 11-13 anos de idade - 5,93 - foi inferior ao índice medido em 1993 para escolares de 12 anos em cidades vizinhas - 8,23 -, cujo índice de desenvolvimento humano medido pelo Programa das Nações Unidas para o Desenvolvimento foi classificado como médio. Os índios, no entanto, apresentaram índice de cuidado muito inferior, por grupo etário, que estas cidades, e uma elevada proporção de dentes perdidos para pessoas acima de 20 anos. Estas observações indicam baixa incorporação de serviços odontológicos. A irregularidade dos serviços programados para estas comunidades, assim como alterações em seus padrões alimentares e culturais, reforçam a necessidade urgente de iniciativas de promoção de saúde dirigidas a estes grupos.

\section{REFERENCES}

1. ANDO, T.; HIRATA, J.M.; MORI, M.; RIBEIRO, F.C. \& RIGONATTO, D.D. - Atuação odontológica no Parque indígena do Xingu: dados de 5 anos de prevenção de cárie com aplicação de flúor-gel. In: Enciclopédia Brasileira de Odontologia. São Paulo, Editora Científica, 1986. v. 4, p. 597-608.

2. DETOGNI, A.M. - Levantamento do índice CPOD: média por idade. In: FORTES, M.C.F. De volta às origens. Rev. Ass. bras. Odont. Nac., 2: 138-148, 1994.

3. DONNELLY, C.J.; THOMSON, L.A.; STILES, H.M. et al. - Plaque, caries, periodontal diseases and acculturation among Yanomamö Indians, Venezuela. Community Dent. oral Epidem., 5: 30-39, 1977.

4. GALVÃO, E. - Encontro de sociedades: índios e brancos no Brasil. Rio de Janeiro, Paz e Terra, 1979.

5. HARRISON, R.L. \& DAVIS, D.W. - Caries experience of Native children of British Columbia, Canada, 1980-1988. Community Dent. oral Epidem., 21: 102-107, 1993.

6. HIRATA, J.M.; BERGAMASCHI, O.; OLIVEIRA FILHO, A. et al. - Estudo de prevalência de cárie em crianças indígenas do Parque Nacional do Xingu. Rev. Fac. Odont. Univ. S. Paulo, 15: 189-198, 1977. 
7. JUNQUEIRA, C. - The Brazilian indigenous problem and policy: the example of the Xingu National Park. Copenhagen \& Geneva, AMAZIND/IWGIA Document, 1973.

8. MARCUS, M.; REIFEL, N.M. \& NAKAZONO, T.T. - Clinical measures and treatment needs. Advanc. dent. Res., 11: 263-271, 1997.

9. MARTINS, E. - Atlas do desenvolvimento humano no Brasil. Brasília, ESM Consultoria, 1998.

10. NEEL, J.V.; SALZANO, F.M.; JUNQUEIRA, P.C.; KEITER, F. \& MAYBURY- LEWIS, D. - Studies on the Xavante Indians of the Brazilian Mato Grosso. Amer. J. hum. Genet., 16: 52-140, 1964.

11. NISWANDER, J.D. - Further studies on the Xavante Indians. VII. The oral status of the Xavantes of Simões Lopes. Amer. J. hum. Genet., 19: 543-553, 1967.

12. O'SUlliVAN, D.M.; DOUGLASS, J.M.; CHAMPANY, R. et al. - Dental caries prevalence and treatment among Navajo preschool children. J. publ. Hlth. Dent., 54: 139-144, 1994.

13. PINTO, V.G. - Estudo epidemiológico sobre prevalência da cárie dental em crianças de 3 a 14 anos: Brasil, 1993. Brasília, Serviço Social da Indústria, 1993.
14. RIBEIRO, D. - Os índios e a civilização: a integração das populações indígenas no Brasil moderno. 3. ed. Petrópolis, Vozes, 1979.

15. TUMANG, A.J. \& PIEDADE, E.F. - Cárie dental, doenças periodontais e higiene oral em indígenas brasileiros. Bol. Ofic. sanit. Panamer., 64: 103-109, 1968.

16. VILLAS BÔAS, O. \& VILLAS BÔAS, C. - A marcha para o Oeste. 4. ed. São Paulo, Globo, 1994.

17. WALDMAN, H.B. - "Rediscovering" the health status of Native Americans. J. Dent. Children, 59: 216-220, 1992.

18. WALSH, J. - International patterns of oral health care - the example of New Zealand New Z. dent. J., 66: 143-152, 1970.

19. WORLD HEALTH ORGANIZATION - Oral health surveys: basic methods. 3. ed. Geneva, World Health Organization, 1987.

20. WORTHINGTON, H.V. \& CRAVEN, R.C. - Relationship between the care index and mean dmft/DMFT. Community dent. Hlth., 15: 248-251, 1998.

Received: 11 August 2000

Accepted: 16 November 2000 